Let me but find it in my heart to say When vagrant wishes beckon me astray, 'This is my work: my blessing, not my doom, Uf all who Jive, I am the one, by whom This work can best be done in my own way, 'Then shall I see it not too great nor small To suit my spirit and to prove my powers; Then shall I cheerfully greet the laboring hours, And eheerfully tu'n when the long shadows fall, At eventide, to play and love and rest, Because I know for me my work is best."

\title{
NURSING IN MISSION STATIONS: INDIA
}

'I'He Mary 'l'aber Sehell Memorial Hospital of Vellore, India, which is now in its fourth year, issues an interesting illustrated report of its last year's work. 'The hospital and dispensary are in charge of two women physicians assisted by a trained nurse, Miss Lillian M. Hart, as superintendent of a staff of eleven native women who are in training as nurses, and of two who are in the compounding room. The hospital has a eapacity of forty-two beds and admitted eight hundred and sixtyfive new patients during last year. It contains a European ward for the use of missionary and civiliun ladies which has been oceupied the greater part of the year. Over thirty thousand "out-patients" have been treated. Many important operations are performed in the hospital, and the picture of the operating-room shows as commodious and well-kept a place for work as one could wish. Some of the patients who are unwilling to remain in the hospital are operated upon in the dispensary and are taken to their homes a short time after recovering from the anesthetic. The dispensary is open from seven to twelve A.M. and from three to five P.M.

In the morning the patients are seen free of charge, except that they put half a cent into a box for the purpose, to pay for their chit, a small piece of paper on which is written their name, number and date for reference when they are to come again. In the afternoon a small fee of about sixteen cents is charged, so very few come at this time, but when they do they are seen more carefully and there is time for a little personal talk with them. As each one makes ler final visit she is encouraged to plaee a thank-offering in the charity box, and all who can are asked to pay for their medicines. The amount thus obtained has increased with each sueceeding year.

Some of the diffieulties encountered in the dispensary work are described thus: 
"You who in the homeland read this will, I fear, in thinking of a dispensary, think of the quiet, orderly institutions as they are at home, where there is a clerk to receive each arrival, give her her number for the day, and direct her to the right room, to the door of whieh they quietly go, sit down and await their turn to be seen. There are several rooms for the various kinds of diseases and a doctor for each room. Not so here. Although there is some one to give out numbers, she usually gets them mixed up, or the people rush by it they can, four or five of the family with eaeh, and they all must talk at once and each one who comes pretends that she eannot possibly wait at all but must be seen at once. While some one is trying to keep order at one door whold a whole floek of white-robed creatures enter at another (the Gosha door for purdah women only) and we are surrounded at once by a lot of chattering Muhammadan women. As these are fewer in number thall the Hindus we cannot afford to devote a door keeper for them, so they come in unehecked, and although the doetor uny be talking seriously witl another patient, unless quieted, they will all begin to talk and keep it up till they are heard. We are so glad to have one with us who fully understands their language and ean speak to them and quiet them at once. There is a time in the morning when a large number arrive about the samc time, so that one's nerves are pretty well tried by the time a hundred have been seen and sent on. The trouble of it is they are not content to be seen only once and sent on, but must eome baek to tell of things they forgot, or to ask questions they have or have not asked before and to have direetions repeated to them not less than six or seven times. Sometimes when we laugh at them or scold them they only say, "We are only women, how can we remember and understand all you say, you must come and talk to the inen.' and then nothing must do but that the doctor leave her seat and go out where the men are and repeat everything necessary to be told once more and to hear onee more a full rehearsal of all the subjeetive symptoms anl then they are usually satisfied for the day."

Miss Hart reports that the progress of the nurses in practical work has been fairly favorable, but owing to fever she has not been able to carry on much class work. Considering the difficulties to be overcome. and their nationality, their improvement as nurses has been wonderful. The day's work begins at six forty-five A.M. and is finished at scven P.M. with a period of two lours off duty for each nurse for rest and food. 'The nurses have their lolidays during the cold season when the hospital work is slack.

St. Lukf's Hospital, Philadelphia, Pennsylvania, has recently opened two new wards, one for surgical, and the other for obstetrical cases. Thesc additions are in two buildings, one story high, connected with the main huilding by corridors. Each contains sixteen beds and has a sun-parlor.

"Character is nature in the highest form." 